\title{
A távolsági ingázás néhány demográfiai sajátossága
}

\author{
BALCSÓK ISTVÁN ${ }^{1}$
}

\begin{abstract}
ABSZTRAKT
A tanulmány az elérhetô legfrissebb statisztikai adatokat felhasználva kívánja bemutatni a huzamos ingázásban résztvevő munkavállalók legfontosabb demográfiai jellemzőit, illetve a kirajzolódó területi egyenlötlenségeket. Az ingázás, ezen belül a huzamos ingázás fö motivációja napjainkban is a megfelelőnek ítélt munkahely elérése, mintegy negyedmillió ember ugyanakkor az átlagosnál sokkal nagyobb terheket vállal fel ennek érdekében, és csak hetente vagy ritkábban utazik haza. Többségük kényszerből dönt így, mivel lakóhelyükön nincs munkalehetőség, a családjuknak viszont nagyon fontos az általuk biztosított bevétel. A huzamos ingázók javarészt szezonális munkát végeznek (építôipar, vendéglátás stb.), és fizikai munkakörben dolgoznak. Nem meglepö módon sokkal inkább a férfiak vállalják fel a fokozott fizikai és lelki megterheléssel járó életformát, azonban nem csupán a negyvenes éveikben járó családfók, hanem a családjuktól még nem függetlenedő huszonéves fiatalok is nagy létszámban képviseltetik magukat. A huzamos ingázás markáns területi egyenlőtlenségekkel jellemezhetö, és az érintettek döntöen falvakból indulnak útra annak ellenére is, hogy a leghátrányosabb helyzetben lévő térségekben a közfoglalkoztatás magas szintje a munkaerő helyben maradásának irányába hat.
\end{abstract}

KULCSSZAVAK: huzamos ingázás, területi egyenlőtlenségek, demográfiai jellemzők

\section{ABSTRACT}

\section{Some demographic characteristics of long-term commuting in Hungary}

The study aims to show the most important demographic characteristics of long-term commuting workers and the emerging territorial disparities using the latest available statistics. The main motivation for commuting, including long commuting, is still to get the job they deem appropriate, but about a quarter of a million people take on much greater burdens than average and only travel home weekly or less frequently in Hungary. Most of them make this decision by force, as there are no job opportunities in their place of residence, but the income they provide is very important for their families. Long-term commuters mostly do seasonal work (construction, catering, etc.) and work in physical jobs. Unsurprisingly, men are more likely to take on the life form with increased physical and psychological strain, but not only the heads of the family in their forties, but also young people in their 20s who are not yet independent of their families are represented in large numbers. Long commuting is characterised by marked territorial inequalities, and those affected mainly start from villages, despite the fact that the high level of

\footnotetext{
${ }^{1}$ Debreceni Egyetem, Szociológia és Szociálpolitika Tanszék, balcsok.istvan@arts.unideb.hu
} 


\section{TEMATIKUS TANULMÁNYOK - „Hetelők” Kelet-Magyarországon}

public employment in the most disadvantaged areas is affecting the direction of the stay of the workforce.

KEYWORDS: long-term commuting, territorial inequalities, demographic characteristics

\section{Bevezetés}

Napjainkban a földrajzi mobilitás, illetve kifejezetten a nemzetközi migráció szinte folyamatosan kiemelt figyelmet kap, és ezen belül (a külföldön munkát vállaló honfitársainknak a korábbi évtizedekben elképzelhetetlenül magas létszáma miatt) az országok közötti munkaerő-áramlás is számos diskurzus alapját képezi. Mindez egyáltalán nem meglepő, de arról a szakemberek által régóta hangoztatott tényről sem szabad megfeledkezni, hogy a teljes volument tekintve ez utóbbinak viszonylag csekély szerepe van, sokkal jellemzőbb a munkaerő kisebb földrajzi távolságokat felölelő mozgása (Kovács - Egedy - Szabó 2015, idézi Illés - Kincses 2012).

Az országon belüli ingázás sok szempontból jelentősen átalakult az elmúlt évtizedekben, és a változások természetesen a hosszabb távolságot és/vagy időtartamot felölelő, huzamosnak vagy távolságinak nevezett vállfajt sem kerülték el. A főbb trendekről azonban csak meglehetősen tág időközönként kaphatunk átfogó, az egész országot lefedő részletes adatokat, mivel ezeket (néhány kivételtől eltekintve) a cenzusok alkalmával gyűjti be a statisztikai hivatal.

A vonatkozó szakirodalom általános szabályszerűségként az egyén által megfelelőnek ítélt munkahely elérését jelöli meg a munkaerő-áramlás fő mozgatórugójának, az viszont különösen érdekes kérdés, hogy kik vállalják annak a minden szempontból legmegterhelőbb formáját. Az alábbiakban rövid történeti áttekintést követően az elérhető legfrissebb statisztikai adatok felhasználásával igyekszünk bemutatni az ingázás, azon belül kiemelten a huzamos ingázás területi sajátosságait, illetve az abban résztvevők legfontosabb demográfiai jellemzőit - végeredményként megrajzolva napjaink „tipikus” távolsági ingázójának profilját.

\section{Az ingázás múltbeli trendjei Magyarországon}

A magyar társadalom migrációs hajlandóságát a múltban (és javarészt napjainkban is) jelentősen befolyásolta a saját tulajdonban lévő lakásokhoz, illetve a megszokott élettérhez való ragaszkodás, így annak szintje „meglehetősen alacsony” maradt (Dövényi 2009). A lakó- és munkahelyek egymástól való elkülönülése azonban már a XX. század elejétől azt eredményezte, hogy egyre nagyobb lett az olyan munkavállalók száma és aránya, akik egy vagy több közigazgatási határt átlépve - főként Budapest akkori elővárosaiból - jártak munkába (Beluszky 2004). Az ingázás robbanásszerű emelkedését azonban a vidék iparosítása, az üzemek hirtelen megugró munkaerőigénye hozta magával. 


\section{TEMATIKUS TANULMÁNYOK - „Hetelők” Kelet-Magyarországon}

Az ekkor teret hódító „kétlaki életmód” egyik fontos, a munkaerő földrajzi mobilitását máig meghatározó tényezője volt a humán infrastruktúra, ezen belül a lakhatási feltételek javítását szolgáló beruházások szükségesnél jóval alacsonyabb volumene. A falvakból tehát sokan nem tudtak városba költözni, és a háztáji gazdaságokból származó kiegészítő jövedelmek is hozzájárultak ahhoz, hogy az ezzel járó kényelmetlenségek ellenére is az ingázást válasszák.

A rendszerváltás sok szempontból jelentős változásokat hozott az ingázási szokásokban, ugyanakkor a gazdasági recesszió és a tömeges leépítések ellenére sem csökkent a más településen dolgozó munkavállalók aránya, a 2000-es években pedig számottevő növekedésnek indult. A jelenség mögött meghúzódó számos tényező közül kiemelhetjük a szolgáltató szektor térnyerését, a népesség és a munkahelyek koncentrálódását Budapest és a nagyvárosok agglomerációiban, a szuburbanizációs folyamatokat, a személygépkocsi-állomány dinamikus növekedését, illetve a centrum- és perifériaterületek lakás- és munkaerőpiaci jellemzői között tovább mélyülő szakadékot, ami a fejletlen térségekben a kényszerből vállalt ingázás irányába hat (Hardi 2015).

A helyi munkalehetőségek szűkössége miatt a külső és belső perifériaterületeken tehát fokozott jelentősége van a nem helyben történő munkavállalásnak. A meglévő ingázási kapcsolatok azonban erősen viszonylagosak és instabilak, mivel azok intenzitása a munkaerőpiac dinamikájából következően akár nagyon gyorsan változhat, egy üzem bezárása például teljesen fel is számolhatja őket (Pénzes 2013).

A gazdaságilag kevésbé fejlett, a foglalkoztatási centrumok megközelíthetősége (idő, távolság és költségek) szempontjából kedvezőtlen adottságokkal rendelkező, a hátrányos helyzetű társadalmi csoportok (romák, alacsony iskolázottságúak vagy nem piacképes szaktudással rendelkezők, egészségkárosodottak stb.) magas arányával jellemezhető kistelepüléseken az ingázás relatív felértékelődése tehát egyben nagyobb kiszolgáltatottságot eredményezett. A mezőgazdaságból felszabaduló munkaerő (kollektivizálás, gépesítés, foglalkozási átrétegződés) révén a több évtizedes távlatban is népességkibocsátó periférikus aprófalvak szempontjából azonban korántsem volt (és maradt) mellékes kérdés, hogy a munkavállalók mobilitása megállt-e az ingázásnál, vagy lakóhelyváltással járt együtt.

A nem a lakóhelyükön munkát vállaló foglalkoztatottakra vonatkozó hivatalos információkat a népszámlálások (illetve eseti, célzott KSH adatfelvételek) szolgáltatják, elsőként az 1960. évi során gyűjtötték össze őket. A korábbi évtizedekről megbízható adatok nem állnak rendelkezésre, de amint azt fentebb említettük, a második világháborúig az ingázás becslések alapján mintegy 100-150 ezer főt érintve gyakorlatilag a főváros környékére koncentrálódott (és még ott is meghatározóak voltak az egyes települések mezőgazdasági adottságai, eltartóképessége). Az 1960as cenzus alapján ugyanakkor már 612 ezer főt (a foglalkoztatottak 12,5\%-át) regisztráltak ingázóként - amiben az előzőekben felsorolt okokon kívül igen nagy sze- 
repet játszott a tömegközlekedés, elsősorban a vasúti kapcsolatok jelentős fejlődése (Kovács et al. 2015).

Az 1960-as évek ingázási viszonyairól a népszámlálás mellett egy 1966-ban készült összeírás is ad támpontokat. A cenzus adatai szerint főként a fizikai munkát végző fiatal férfiak vállaltak munkát más településen (főként a nagyobb ipari központokban), és figyelemreméltó, hogy a lakóhelyükről eljárók 90\%-a élt községekben. Az évtized közepén készült felmérés azt mutatta, hogy az ingázások zöme a „szúkebb pátriában” zajlott, mindössze 13\%-uk lépte át a megyehatárokat. A távolsági ingázás szempontjából kiemelendő sajátosság, hogy a mintegy 900 ezer főre tehető ingázó foglalkoztatott egyötöde csak hetente vagy annál is ritkábban utazott haza (Kovács et al. 2015).

Az ingázók száma 1980-ig folyamatosan növekedett, ekkor a foglalkoztatottak negyede (1,2 millió fő) vállalt így munkát. A tradicionális (falu-város viszonylatban történő, az iparba irányuló) munkaerőmozgás csúcspontján volt a legmagasabb a távolsági ingázók létszáma is. A tudatosan közlekedtetett ingajáratok közül máig emlegetik az elhíresült „fekete vonatokat”, amelyek a Mátészalka-Budapest útvonallal a periférikus aprófalvas térségből a fejlett ipari központba történő nagy távolságú ingázás megtestesítői voltak. Szabolcs-Szatmár-Bereg aprófalvas térségeire egyébként is jellemző volt, hogy akik nem kaptak munkát a helyi téeszben vagy a térségi központokban (Fehérgyarmat, Mátészalka stb.), azok az ország nagyvárosaiba - elsősorban Budapestre, Debrecenbe, Miskolcra - jártak el dolgozni, és ennek főként a szakképesítéssel nem rendelkezők körében volt meghatározó szerepe (Rácz 2009).

A távolsági ingázók számának csökkenését azonban már az évtized közepétől prognosztizálni lehetett, mivel jellemzően a legkevésbé iskolázott, a munkaerőpiacon legkönnyebben helyettesíthető, tehát leginkább kiszolgáltatott foglalkoztatottak tartoztak ebbe a csoportba, a szocializmus válságjelenségei őket érintették a leghamarabb. Bár a rendszerváltást követően a munkaerőmozgásban részt vevő foglalkoztatottak aránya gyakorlatilag nem csökkent, a létszámuk azonban egészen 1997ig igen, és mivel leginkább a távolsági ingázás feltételei alakultak át leginkább ebben az időszakban, így bizonyosra vehetjük, hogy annak volumene radikálisan csökkent (Forray R. 2008). A jelenség természetesen nem tűnt el (hagyományos értelemben sem), de szerepét új formák vették át, mint pl. a nem fix, több telephelyre történő ingázás - építőipar, kereskedelem, ügynökök stb. -, a külföldi munkavállalás vagy a távmunka.

A 2000-es évek elejéről rendelkezésre álló adatok alapján teljesen domináns szerep jutott a helyben foglalkoztatásnak és a rövid távolságra történő napi ingázásnak: 14 megyében az ingázók kétharmada nem lépte át saját megyehatárát, 12-ben és Budapesten pedig 90\% fölött alakult az egyáltalán nem, vagy csak a megyén belül ingázó munkavállalók aránya. A munkaerőpiac szerkezeti átalakulását és polarizáltságát jelzi, hogy míg a főváros közel 150 ezer fős, a helyben foglalkoztatottak ötödét kitevő „ingázási nyereséget” könyvelhetett el (ennyivel érkeztek többen, mint ahányan el- 
ingáztak), addig 14 megye kisebb-nagyobb veszteséggel rendelkezett. A szembeötlő különbségek azonban ezeken belül is tetten érhetők voltak: Pest megyéből pl. 110 ezerrel többen ingáztak el (zömmel Budapestre), mint ahányan oda, az elmaradottabb régiókból viszont alig volt ilyen jellegű kiáramlás (Forray R. 2008).

A fentiek alátámasztják a távolsági ingázás számottevő térvesztését, a piacorientáció-váltást követően a multinacionális cégek által preferált régiók túl messze kerültek (a földrajzi távolság és főként a szárnyvonalakon leépülő tömegközlekedés együttes hatásaként), az utazási költségek jelentősen emelkedtek, miközben a modern technológiák, a tudásalapú gazdaság térhódításával a szakképzetlen munkaerő iránti kereslet érezhetően csökkent. Az ingázási, ezen belül a távolsági ingázási lehetőségek drasztikus beszükülése vagy megszűnése ugyanakkor messzebb mutat az egyének problémáinál, a településhierarchia legalján elhelyezkedő településeken ugyanis könnyen felerősítheti az egyébként is meglévő társadalmi és gazdasági problémákat (Kovács et al. 2015).

\section{Az ingázás és munkába járás néhány sajátossága napjainkban}

Az ingázás területi és társadalmi sajátosságairól a legfrissebb információkat a 2011. évi népszámlálás, valamint a KSH 2017. negyedik negyedévében, az aktuális munkaerő-felméréshez csatolt tematikus adatfelvétel szolgáltatja (hasonló készült 2008 első negyedévében is). Az adatok legfőbb tanúsága, hogy a korábbi évtizedekkel öszszehasonlítva folytatódott a lakó- és munkahelyek elkülönülése, mert a gazdaság fejlődésével egyre összetettebbé váló munkafolyamatok, az urbanizáció és egyéb tényezők is ebbe az irányba hatottak (a távmunka megjelenése ugyanakkor épp ellentétesen, de még kisebb mértékben). Mindezek alapján nem meglepő, hogy 2008ban az összes foglalkoztatott 94,5\%-a közlekedett a munka- és lakóhelye között, zömük számára ez napi szinten igényelt több-kevesebb időráfordítást (KSH 2009).

A lakó- és munkahely szétválása ugyanakkor továbbra sem feltétlenül jelenti azt, hogy az érintetteknek más településen kell munkát vállalnia: mivel a munkahelyek és a népesség egyaránt Budapesten és a nagyvárosokban koncentrálódnak, a foglalkoztatottak 60\%-a nem lépett át településhatárt. A fennmaradó egyharmad ingázott (ez az arány megfelel a volt szocialista országok átlagának), és mintegy négyötödük ezt napi rendszerességgel tette. A KSH definíciója alapján napi ingázónak az minősül, aki „nem ugyanazon a településen dolgozik, mint ahol ténylegesen lakik (mint amelyik település lakónépességébe beletartozik). A naponta ingázók a tényleges tartózkodási helyük szerinti település oldaláról más településre eljárók, a munkahely szerinti település oldaláról pedig más településről bejárók." (KSH Népszámlálás 2001)

A meghatározás második fele az elmúlt évtizedekben egyre nehezebbé vált, mivel a szolgáltató ágazatok térnyerésével egyre magasabb lett a nem egy, hanem több helyszínen dolgozók aránya. Ha a munkavégzés helyszíne a településen belül 


\section{TEMATIKUS TANULMÁNYOK - „Hetelők” Kelet-Magyarországon}

változik, az nem befolyásolja az ingázási adatokat, az érintettek jelentős része viszont több telephelyre is eljárhat, vagy a szállításban, építőiparban, ügynökként stb. dolgozva távolsági ingázóként járhatja az országot. A 2001. évi cenzust megelőzően nem regisztrálták a változó településen dolgozókat, 2011-ben viszont már 153 ezer fő (a foglalkoztatottak közel 4\%-a) jelent meg az összeírásban - vagyis a módszertan változása tehát befolyásolhatta az ingázásra és a távolsági ingázásra vonatkozó adatokat (KSH 2015).

A migráció egyik általános jellemvonása, hogy abban általában felülreprezentáltak a fiatalabb korosztályok, és inkább a férfiak vesznek benne részt, mivel könynyebben viselik a kényelmetlenségeket, és főként családalapításukat megelőzően függetlenebb életformát választhatnak. Mindehhez hozzájárul, hogy jelentős részük már tanulmányai alatt is ingázik, és végzettségük megszerzése után szeretnének a vonzásközpontban maradni. Magyarországon ugyanakkor számolni kell a népesség elöregedésével, és ez a folyamat a foglalkoztatottak és az ingázók esetében is nyomot hagy a korösszetételen, egyre inkább a középkorosztályok felé tolódást eredményezve.

Ezzel együtt a 2011-es népszámlálás adatai megerősítik, hogy az ingázási hajlandóság az életkor növekedésével párhuzamosan csökken: miközben a 20-24 évesek körében 40\% fölött volt az eljárók aránya, addig 55 éves kor felett ez már az egyharmadot sem érte el. Az ingázók körében ugyan a 20. század második felétől folyamatosan emelkedett a hölgyek aránya, 2011-ben továbbra is jelentősen magasabb arányban vettek benne részt a férfiak (a foglalkoztatott nők 28,7\%-a ingázott, az erősebb nem esetében 10 százalékponttal volt magasabb a mutató). A változó településen dolgozókat tekintve még markánsabb a különbség: a férfi ingázók 17,1\%-ával szemben a bők mindössze 2,7\%-a vállalt ilyen keretek között munkát.

Az iskolai végzettség a teljes népességhez és a foglalkoztatottakhoz hasonlóan a rendszerváltás óta jelentősen emelkedett az ingázók körében is, azonban jellemzően még mindig az alacsonyabb iskolázottságúakra jellemző a települések közötti munkaerőmozgás (kivéve az alapfokú végzettséggel sem rendelkezőket - lásd lentebb). Ez annak ellenére így van, hogy 1990 és 2011 között csaknem megduplázódott az ingázó diplomások aránya, és 28,9\%-ra emelkedett. Más kérdés, hogy esetükben ez sokkal inkább választás kérdése lehet - az agglomerációkba költözést követően járnak vissza Budapestre és a nagyvárosokba -, mint az ingázást (helyi munkalehetőség hiányában) a legtöbb esetben kényszerből vállaló alacsonyabb iskolázottságúaknál.

Ez utóbbi megállapítást támasztotta alá a KSH 2008. évi tematikus adatfelvétele is: az akkori 1 millió 273 ezer ingázó többsége kényszerből járt el a lakóhelyéről, főként azért, mert helyben nem talált magának semmilyen munkalehetőséget $(53,8 \%$ nyilatkozott így). Az ingázók negyede azért vállalta a kényelmetlenségeket és a plusz ráfordításokat, mert végzettségének megfelelő munkakörben kívánt dolgozni, 10\% egyértelműen az elérhető magasabb fizetések miatt döntött így, és mindössze négy 


\section{TEMATIKUS TANULMÁNYOK - „Hetelők” Kelet-Magyarországon}

százalékuk választotta azért ezt az életformát, mert ragaszkodott a lakóhelyéhez (KSH 2009).

A 2017. negyedik negyedévi felmérés adatai ugyanakkor jelentős átrendeződést mutattak ebben a tekintetben, az utóbbi esztendők munkaerőhiányt eredményező gazdasági fellendülése visszatükröződött a válaszokban. A saját településükön semmilyen munkalehetőséget nem találók aránya drasztikusan visszaesett (13,9\%), az ingázás elsődleges kiváltójává a végzettségnek megfelelő állás hiánya (51,8\%) lépett elő. Jelentősen, konkrétan a duplájára növekedett a helyben elérhető bérszínvonalat túl alacsonynak ítélő, és ezért más településen munkát vállaló válaszadók aránya (20,3\%), és még ennél is nagyobb mértékű emelkedés eredményeként már a megkérdezettek egytizede ingázott azért, mert nem kívánt elköltözni a lakóhelyéről.

Korábban már többször említettük, hogy a gazdasági fejlettség mellett a településhálózat szerkezete is komoly hatást gyakorol az ingázásra, a munkahelyek elérhetőségére. Általános szabályszerűség, hogy a községek és nagyközségek által kibocsátott munkaerőt a városok, még inkább a nagyvárosok fogadják be. A 2011-es adatok alapján továbbra is Budapest vonzása volt a legerősebb (az összes bejáró 19,4\%-a dolgozott a fóvárosban, ez megegyezett a tíz évvel korábbival), a legnagyobb munkaerő-nyereséget viszont a megyeszékhelyek könyvelhették el - de korántsem egyforma mértékben. A kisebb városok mérsékelt, míg a községek jelentős (43\%-os) munkaerő-veszteséggel voltak jellemezhetők - természetesen nem mindegyikük, akadnak nyereséget felmutatók is -, és az összes ingázó 51\%-a élt falvakban.

A földrajzi elhelyezkedés abból a szempontból is meghatározó lehet, hogy egy adott térségben mennyire sűrű a települési szövet. A helységek egymástól való távolsága a nagyobb kiterjedésű településekkel rendelkező alföldi megyékben ebből is következően alacsonyabb az ingázás intenzitása (Pénzes 2013 idézi Erdősi 1985). A tömegközlekedés szűkre szabott lehetőségei (kevés és nem a munkakezdéshez és/ vagy annak befejezéséhez igazított járatok stb.) révén még tovább növekvő távolságok. Nem egyedi eset Kishódosé: a határ mentén fekvő községből saját járásközpontjába, az autóbusszal 36,5 km-re fekvő Fehérgyarmatra hétköznapokon is mindössze három járat közlekedik, minimum 70 perces menetidővel (az adatok a menetrendek. hu oldalról származnak).

Bár elvben a helybeni munkalehetőségek szinte teljes hiánya még a finoman szólva nehézkes közlekedési lehetőségek ellenére is az ingázás irányába ható tényező, annak intenzitását viszont az elmaradott térségekben található falvak társadalomszerkezeti sajátosságai tovább csökkentik. A jellemzően alacsonyabb iskolázottság, a társadalom peremére szoruló (főként, de nem kizárólagosan roma) népesség átlagosnál magasabb részaránya az eleve hátrányos munkaerőpiaci helyzettel párosulva kifejezetten kedvezőtlenül hat az immobilitásra kárhoztatottak arányára.

A 2011. évi cenzus adatai azt mutatják, hogy az általános iskola 8 osztályánál kevesebbet befejezők körében igen alacsony a munkaerőmozgás, alig több mint egyötödük (20,9\%) ingázik. Több más tényező mellett ennek az a legfontosabb oka, hogy 


\section{TEMATIKUS TANULMÁNYOK - „Hetelők” Kelet-Magyarországon}

nagy hányaduk kiszorul az elsődleges munkaerőpiacról, és az alkalmi munkák mellett gyakorlatilag évtizedek óta a másodlagos piac közfoglalkoztatási programjaira (és jobb híján a jelentősen szűkülő szociális ellátásokra) alapozzák a megélhetésüket. A közfoglalkoztatás viszont meghatározottan a lakóhelyhez kötött, nincs szükség ingázásra, és a jellemzően alacsony jövedelemszint miatt az érintettek általában még adódó munkalehetőség esetén sem tudják vagy akarják vállalni a napi utazási költségeket - a számukra általában elérhető bérek sem teszik ezt lehetővé (1. ábra).

A gazdasági, közlekedési, jövedelmi és egyéb feltételek mellett az ingázás tekintetében meghatározóak az egyéni döntések. Az emberek mérlegelés alapján csak egy bizonyos időmennyiséget hajlandók áldozni a munkába járásra, és amennyiben az meghaladja a számukra még elfogadható szintet, akkor az ingázás helyett inkább már a munkalehetőséget biztosító településre vagy annak közelébe költözést választják (KSH 2015). Paradox módon a munkába járásra fordított idő Budapesten és a nagyobb városokban az ott lakó helyben foglalkoztatottak számára akár több is lehet, mint egy faluból egy kisvárosba történő ingázás esetén, összességében azonban a napi ingázók hosszabb ideig közlekednek lakó- és munkahelyük között, mint nem ingázó társaik.

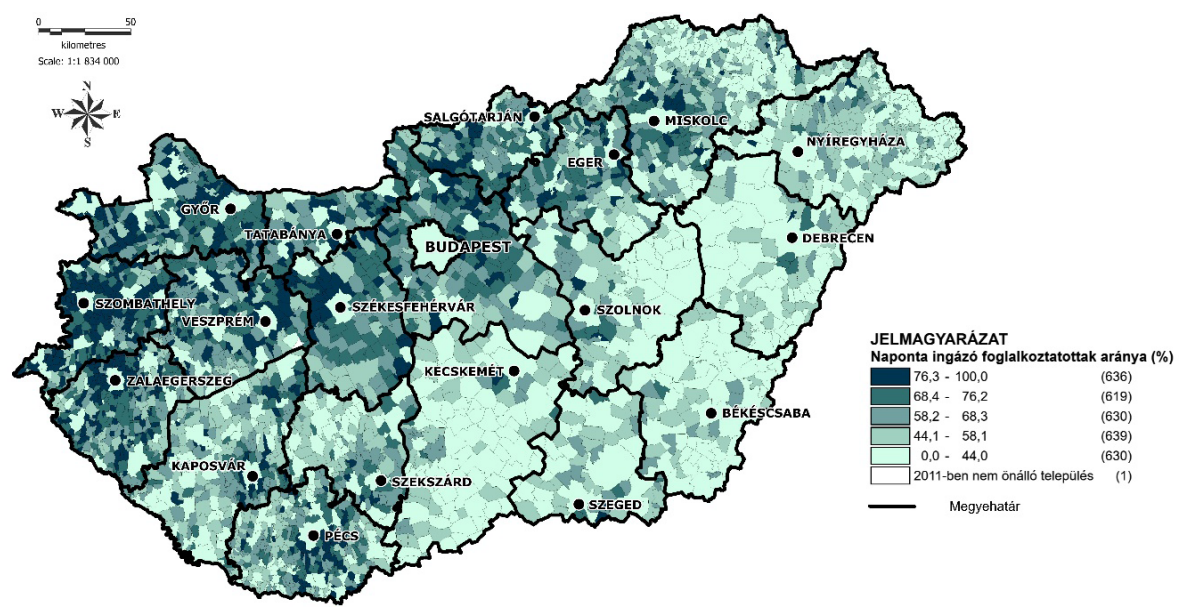

1. ábra. A naponta ingázó foglalkoztatottak aránya településenként 2011-ben Forrás: saját szerkesztés a KSH népszámlálási adatai alapján

Ezt a megállapítást támasztja alá, hogy 2011-ben minden huszadik foglalkoztatott dolgozott a lakóhelyétől legalább $50 \mathrm{~km}$ távolságra lévő településen - és a fentebb már emlegetett kényszerre utal, hogy közülük minden második napi rendszerességgel tette meg ezt az utat. Az oda-vissza legalább 100 km távolság leküzdéséhez értelemszerűen sokkal több idő is kell az átlagosnál, és miközben a foglalkoztatottak fele 


\section{TEMATIKUS TANULMÁNYOK - „Hetelők” Kelet-Magyarországon}

félóránál is kevesebbet közlekedett munkavégzési céllal, addig közel félmillió ember legalább háromszor ennyit, ezen belül 212 ezer fő két óránál is többet volt kénytelen fordítani ugyanerre (a leggyakoribb összességében a 16-60 perces oda-vissza intervallum, 60\%-os részaránnyal).

\section{A nem napi rendszerességú ingázás demográfiai jellemzői}

A 100 km és a másfél-két órás időráfordítás már olyan nagyságrendet képvisel, ahol az érintettek már kénytelenek elgondolkodni a napi ingázás (főként hosszabb távon történő) fenntarthatóságán. Ha a költözés anyagi vagy egyéb okok miatt nem jöhet szóba, akkor az egyetlen reális lehetőség a távolsági vagy más néven huzamos ingázás, elterjedt közkeletű megnevezéssel a hetelés. Természetesen ez is kényszermegoldás, és mindenféle túlzás nélkül kijelenthetjük, hogy az ingázók kisebb, de sok szempontból leghátrányosabb helyzetű csoportját a múltban, illetve napjainkban egyaránt a huzamos ingázók alkották és alkotják (KSH 2015).

A heti vagy ritkább hazautazás azt jelenti, hogy az érintettek az év nagy részében a családjuktól távol, lakhatás és pihenés szempontjából korántsem ideálisnak nevezhető körülmények között (munkásszálláson vagy egyéb ideiglenes helyen) élnek. A lakhatásuk munkaadói oldalról történő támogatásának mértékéről nincsenek pontos információk, de a népszámlálási adatokból azt lehet tudni, hogy az utazási költségeikhez jóval kisebb mértékben járulnak hozzá, mint a napi ingázókéhoz (60\%, illetve $77 \%$ ).

A fentiek alapján nem meglepő, hogy ilyen, az egyénre és a családra nézve egyaránt jelentős plusz terhekkel járó feltételek mellett az életkor még inkább befolyásolja a foglalkoztatottak vállalkozókedvét. Míg a férfiak körében a napi ingázók aránya egészen 50-54 éves korig viszonylag stabilan 30\% körül alakul, addig a huzamos ingázást felvállalók között már nagyjából 40 éves kortól a felére esik vissza a fiatalabb korosztályokra jellemző 10-11\%-os részarány.

A KSH által 2017. negyedik negyedévében, a munkaerő-felmérés keretében lefolytatott adatfelvétel alapján a korábbi, 2008-as felméréshez képest az akkori 188 ezer főről a fentiek ellenére 233 és fél ezerre emelkedett a nem napi ingázók száma. A csaknem 25\%-os növekedés meghaladta mind az összes ingázó (16,6\%), mind pedig a foglalkoztatottak (14\%) esetében megfigyelhető ütemet.

A felmérés adatai alapján a huzamos ingázók több mint kétharmada (68,7\%) férfi, és ez a részesedés jelentősen - közel tíz százalékponttal - magasabb, mint a naponta ingázók esetében. A különbség a munkába közlekedőkhöz hasonlítva még markánsabb, közöttük ugyanis jóval kiegyenlítettebb a nemek aránya, sőt, az ezt naponta megtevők között a hölgyek aránya kicsivel meg is haladja az urakét. Az adatfelvétel során ingázónak tekintették azt a foglalkoztatottat, aki a lakóhelyéről munkahelyére való eljutáskor településhatárt lép át (nem beleértve azokat, akik a munkavégzés 


\section{TEMATIKUS TANULMÁNYOK - „Hetelők” Kelet-Magyarországon}

helyére való eljutás során nagyon változó távokat tesznek meg, ők ugyanis nem válaszolták meg a kiegészítő felvétel kérdéseit). Munkába közlekedőként definiálták azokat, akiknek a lakóhelye és a munkahelye azonos településen van, de itt is érvényes az előző kitétel, kiegészülve az otthon dolgozókkal - a budapesti lakóhellyel rendelkező, a főváros közigazgatási határain belül munkába járók természetesen ide értendők. Itt és a továbbiakban ezeket a meghatározásokat tartottuk szem előtt (2. ábra).

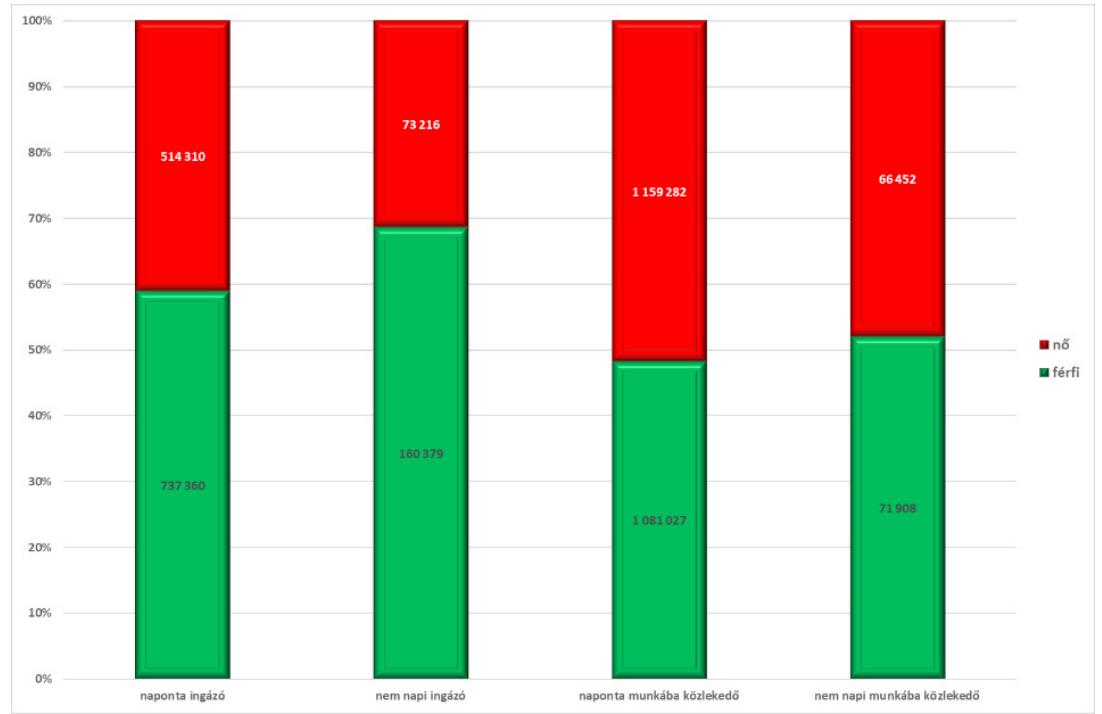

2. ábra. A foglalkoztatottak megoszlása a munkába járás módja és nemek szerint, 2017 (fő)

Forrás: saját szerkesztés a KSH 2017. IV. negyedévi adatfelvételének adatai alapján

Az ingázás, azon belül a távolsági vagy huzamos ingázás felvállalása, illetve az érintett életkora közötti összefüggésre már kitértünk korábban, és az ott leírtakat a 2017 utolsó negyedévében elvégzett adatfelvétel is megerősíti. A 35-49 éves korosztályokban gyakorlatilag megegyezik a napi és nem napi rendszerességgel ingázó, illetve a településhatáron belül munkába járók részesedése saját kategóriájukon belül, míg az idősebbeknél a helyben történő munkavégzés, a fiatalabbaknál pedig az ingázás felé tolódnak az arányok. A nem napi gyakorisággal ingázók negyede kerül ki a 30 évesnél fiatalabbak közül, miközben az 55 éves és idősebb munkavállalók hozzávetőleg 10\%-os részarányt képviselnek (3. ábra).

A legmagasabb iskolai végzettség tekintetében a legfeljebb alapfokú végzettséggel rendelkezők a munkába járás valamennyi formáját tekintve a legalacsonyabb, kiegyensúlyozottan 12-15\% között alakuló részesedéssel bírnak az adatfelvételben 


\section{TEMATIKUS TANULMÁNYOK - „Hetelők” Kelet-Magyarországon}

szereplő foglalkoztatottak között. Az adatok tehát ebben a vonatkozásban is visszaigazolják azt a korábbi megállapítást, hogy az alacsony iskolázottság és a szakképzetlenség negatív irányba befolyásolja az elsődleges piacon történő elhelyezkedés esélyét, ezáltal a mobilitást.

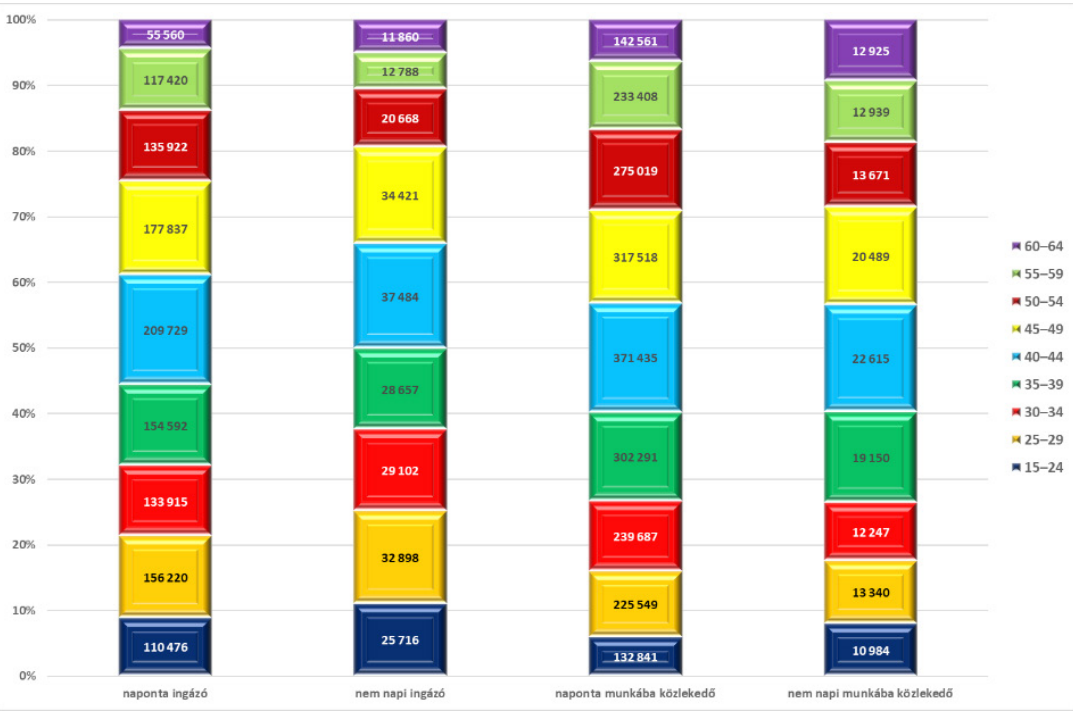

3. ábra. A foglalkoztatottak megoszlása a munkába járás módja

és korcsoportok szerint, 2017 (fö)

Forrás: saját szerkesztés a KSH 2017. IV. negyedévi adatfelvételének adatai alapján

A munkaerőmozgásban leginkább érintett csoportot az érettségizett középfokú végzettségűek alkotják, az ingázók és a helyben munkába járók között egyaránt legalább egyharmados részaránnyal - és a nem napi rendszerességgel ingázók között is ők vannak a legtöbben (37,6\%). A napi és nem napi ingázóknak egyaránt további egyharmadát adják a szakiskolát, szakmunkásképzőt végzettek, és ez 7-8 százalékponttal magasabb, mint a helyben munkába járók esetében. A felsőfokú végzettségüek kevésbé mobilak a fenti két csoporthoz képest, és a naponta ingázók között még 23\% körüli részesedésük (amit vélhetően az agglomerációkból a központi településre bejárás indokol) a heti vagy ritkább ingázási gyakoriságot tekintve 17,7\%-ra csökken (4. ábra).

A magasabb végzettség tehát összességében kisebb kiszolgáltatottságot és könynyebben elérhető munkahelyeket eredményez, amelyek egyben jóval stabilabbak is. A távolabbi munkahelyre kényszerülők esetében ez már korántsem ilyen egyértelmű: a nem naponta ingázók esetében az azt napi rendszerességgel végzőkhöz képest kétszer annyian dolgoznak részmunkaidőben (bár az atipikus foglalkoztatási formák 


\section{TEMATIKUS TANULMÁNYOK - „Hetelők” Kelet-Magyarországon}

szúkösebb elterjedtsége miatt ez is csak 5,2\%-os értéket jelent) - viszont gyaníthatóan sok esetben csak „papíron”. A feltételezést alátámaszthatja, hogy az érintettek mindössze egyötöde dolgozik állami vagy önkormányzati munkaviszonyban, 60\%uk a különféle szolgáltató ágazatokban vállal munkát, és - a többi munkaerőmozgási formához képest kiemelkedő, legalább 10 százalékponttal magasabb értéket felmutatva - zömében $(69,2 \%)$ fizikai munkakörben.

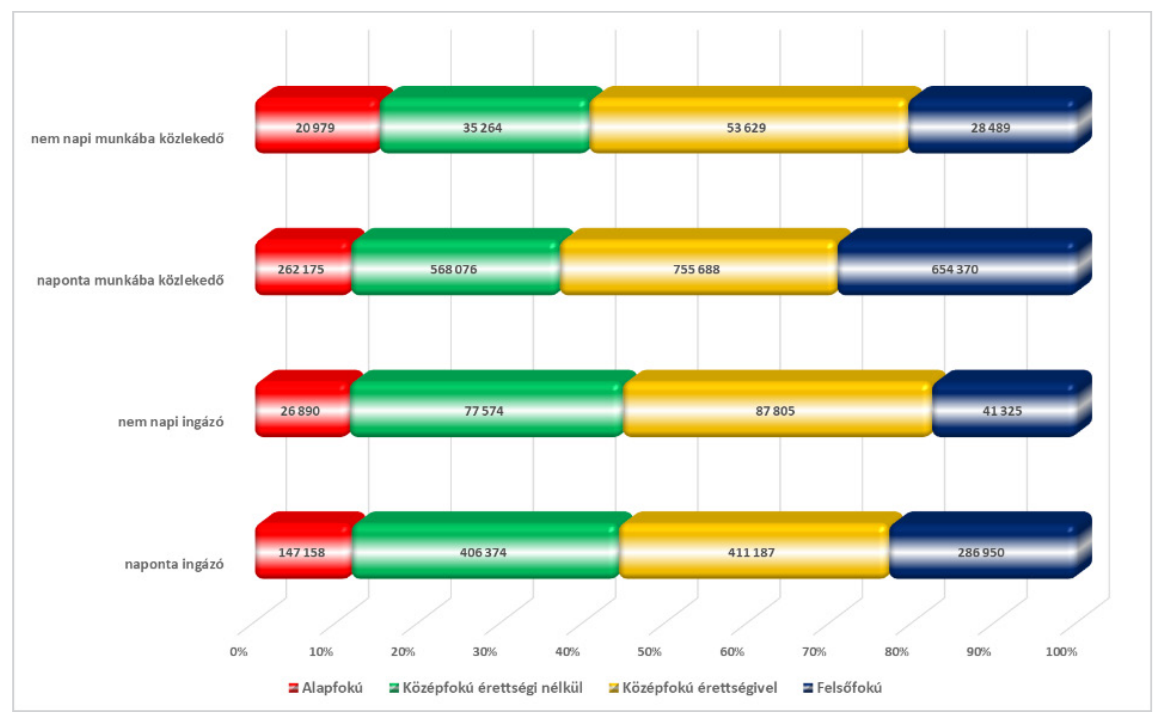

4. ábra. A foglalkoztatottak megoszlása a munkába járás módja és a legmagasabb iskolai végzettség szerint, 2017 (fő)

Forrás: saját szerkesztés a KSH 2017. IV. negyedévi adatfelvételének adatai alapján

A legtöbben gépkezelő, összeszerelő, járművezető foglalkozásúak, akárcsak a naponta ingázók esetében, azokhoz képest viszont érezhetően magasabb a „kereskedelmi, szolgáltatási foglalkozású" kategóriába soroltak aránya (18,4\%). Az adatokban vélhetően megjelennek az üdülőkörzetek, valamint a főváros szállás- és vendéglátóhelyein szezonálisan dolgozók - és mivel az ilyen jellegű vándorlás az építőiparra is jellemző, nem meglepő módon az ipari, építőipari foglalkozásúak 17,7\%-os részaránya ugyancsak jóval magasabb, mint a helyben munkába közlekedők esetében $(11,5 \%)$. A huzamos ingázók kis létszámú, de nagyon sajátos csoportját képviselik a fegyveres testületeknél dolgozók, az összes nem napi rendszerességgel ingázó foglalkoztatottak 1,2\%-át teszik ki - ez az érték hatszorosa a „normál” ingázók, illetve a saját településükön munkába közlekedők esetében megfigyelhetőnek.

Az életkor és a mobilitás, ezen belül az ingázás közötti összefüggésekről fentebb már esett szó, és a betöltött korévek, illetve a családi életciklusok hasonlóan szoros 


\section{TEMATIKUS TANULMÁNYOK - „Hetelők” Kelet-Magyarországon}

kapcsolatát figyelembe véve nem meglepő, hogy a családi állapot, valamint a családon belül betöltött szerep ugyancsak komolyan számításba veendő tényező. A házasok esetében nincs különbség a naponta ingázók és a helyben munkába közlekedők között, egyaránt a felét adják mindkét csoportnak - a huzamos ingázóknak viszont csak 42,4\%-a kerül ki közülük. A helyüket a nőtlenek és hajadonok „veszik át” - ők képviseltetik magukat a legmagasabb arányban $(46,6 \%)$ a hetente vagy ritkábban hazautazók között, 12 százalékponttal meghaladva a helyben munkába közlekedőkre jellemző értéket.

A családi szerepeket megvizsgálva kiderül, hogy a távolsági ingázók között nem az egyedülállók képviselik legnagyobb létszámban a fiatal korosztályokat, hanem a családban élő gyermekek. Utóbbiak 27,5\%-os részaránya megközelíti a családfenntartóként funkcionáló férjekét $(29,8 \%)$, és jelentősen meghaladja a naponta ingázó vagy helyben munkába közlekedő társaikét (18,7\%, illetve 12,6\%) is. Mindez arra is utalhat, hogy az elmaradott térségekben élő és/vagy hátrányos helyzetű családok számára fontos, hogy a keresőképes korúvá vált gyermek akár otthonától távol munkát vállalva aktívan járuljon hozzá a közös költségvetéshez, saját későbbi önállósodásának előkészítéséhez (5. ábra).

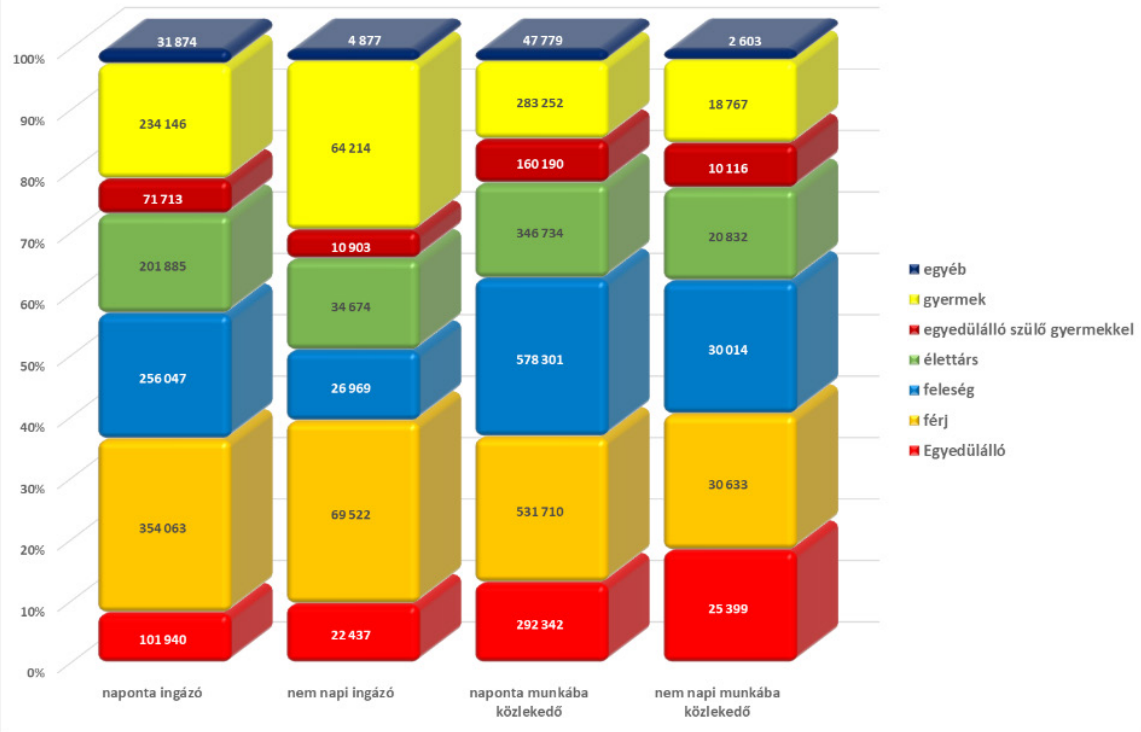

5. ábra. A foglalkoztatottak megoszlása a munkába járás módja és családi állás szerint, 2017 (fó)

Forrás: saját szerkesztés a KSH 2017. IV. negyedévi adatfelvételének adatai alapján

A családok múködése és a felvállalt szerepek (gyermeknevelés, háztartás vezetése stb.) szempontjából érdemes kiemelni azt a tényt, hogy a feleségek a helyben 


\section{TEMATIKUS TANULMÁNYOK - „Hetelők” Kelet-Magyarországon}

munkába közlekedők több mint negyedét, a naponta ingázók ötödét teszik ki, viszont a huzamos ingázók között jóval kisebb (11,5\%-os) arányt képviselnek. A családi szerepek a napi ingázást is sokkal megterhelőbbé teszik a hölgyek számára mentálisan és fizikálisan egyaránt, a huzamosabb időtartammal növekvő kényelmetlenségek és kiszolgáltatottság pedig újabb terheket jelent, ezért a feleségek sok esetben házastársukkal vagy akár több családtagjukkal együtt vállalkoznak csak rá.

A nem napi rendszerességű belföldi ingázás területi sajátosságait megvizsgálva markáns különbségeket tapasztalhatunk mind az érintettek foglalkoztatottakon belüli részarányát, mind pedig az egyes megyéknek a huzamos ingázók teljes létszámából való részesedését tekintve. Az utóbbit sok más tényező mellett jelentősen befolyásolja az adott megyében élő népesség, ezen keresztül pedig a munkavállalási korúak és a foglalkoztatottak száma - ez is magyarázza, hogy miért találhatók a rangsor elején az ország fejlődési centrumaihoz tartozó megyék, mint Pest, Fejér vagy Győr-Moson-Sopron (6. ábra).

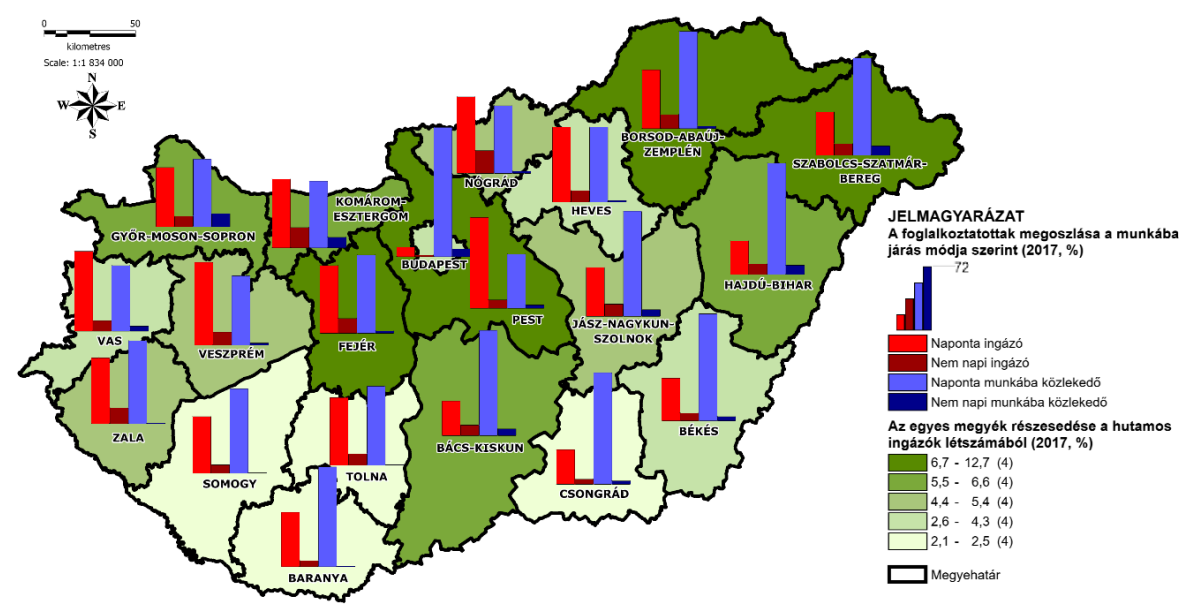

6. ábra. A munkába járás módjának és a huzamos ingázók számának lakóhely szerinti megoszlása megyénként, 2017 (fő)

Forrás: saját szerkesztés a KSH 2017. IV. negyedévi adatfelvételének adatai alapján

A tradíciókat (és a népességszámot) figyelembe véve Borsod-Abaúj-Zemplén és Szabolcs-Szatmár-Bereg 7-9\% körüli értéke még annak fényében sem meglepő, hogy esetükben jóval magasabb a helyben történő munkavégzés súlyát jócskán felerősítő közfoglalkoztatás szerepe. A naponta ingázó foglalkoztatottak arányát tekintve mindkettő a középmezőnyben található, a távolsági ingázókat tekintve viszont több pozícióval kerülnek előrébb - vagyis a korábbi évtizedekre jellemző munkaerő-kibocsátás továbbra is fennáll. 


\section{TEMATIKUS TANULMÁNYOK - „Hetelők” Kelet-Magyarországon}

Az már talán váratlanabbul hat, hogy a hetente vagy ritkábban hazautazó foglalkoztatottak aránya Nógrádban és Komárom-Esztergomban a legmagasabb, csak ezekben a megyékben haladva meg a 10\%-os értéket. Erre, valamint Pest és Fejér szintén jelentős szerepére kézenfekvő magyarázatként szolgál, hogy a legnagyobb munkaerővonzást kifejtő Budapest a megyék bizonyos részeiről már túl messze van a napi rendszerességű utazáshoz, de még nincs túl messze ahhoz, hogy érdemes legyen ott munkát vállalni. Idő- és bizonyos szempontból költséghatékonyabb munkásszállásról vagy bérleményből indulni a napi munkavégzésre, fóként, ha a fentebb már említett szezonalitást is figyelembe vesszük.

A rendelkezésre álló adatokat a települések közigazgatási jogállása szerinti bontásban szemügyre véve egyértelműen látszik Budapest munkaerő-nyeresége: a naponta munkába közlekedőkből a népességszámánál magasabb arányban részesedik, miközben alig jellemző a fővárosból való napi vagy hosszabb időtartamú elingázás. A megyei jogú városokat összességében nézve hasonló a helyzet, bár esetükben már jelentősebb a huzamos elingázásban érintettek száma, a teljes létszám egytizedét kitéve. A kisebb városok köztes helyzetben vannak, az összes naponta és nem napi rendszerességgel ingázó harmadát adják, és esetükben ez a részesedés már meghaladja a helyben munkába közlekedőkre jellemző értéket (7. ábra).

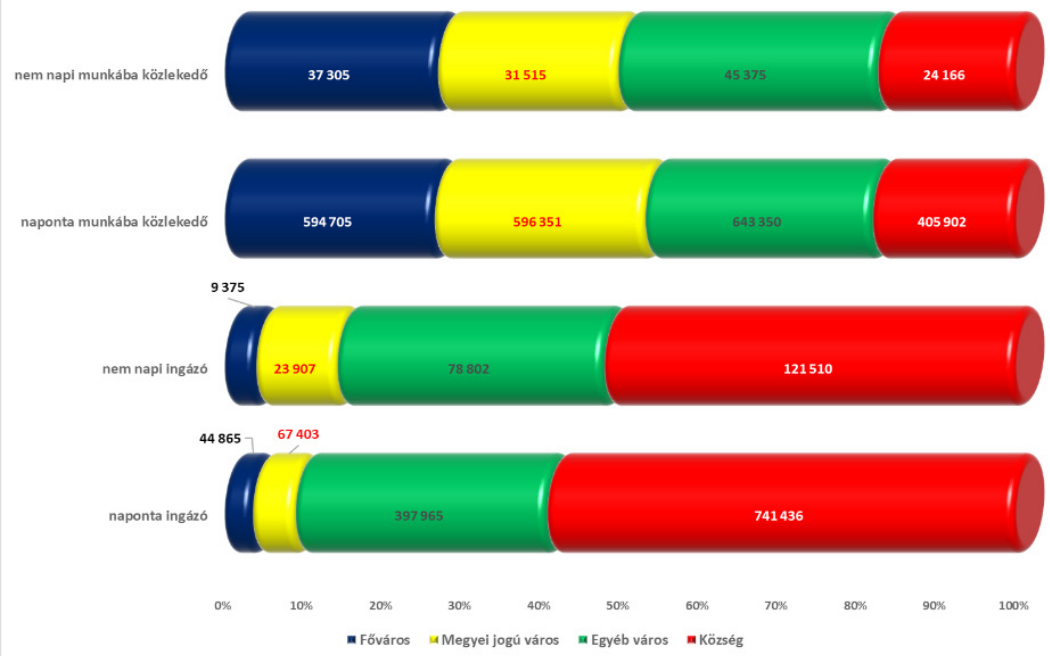

7. ábra. A foglalkoztatottak megoszlása a munkába járás módja és lakóhelyük közigazgatási besorolása szerint, 2017 (fő)

Forrás: saját szerkesztés a KSH 2017. IV. negyedévi adatfelvételének adatai alapján 


\section{TEMATIKUS TANULMÁNYOK - „Hetelők” Kelet-Magyarországon}

A más településre eljáró foglalkoztatottak legnagyobb hányada továbbra is egyértelműen a községekből és nagyközségekből indul el a munkahelyére. Az adatok alapján ez egyértelműen a helyben elérhető megfelelő munkalehetőségek hiányára vezethető vissza, mivel a saját településükön naponta munkába járóknak csak a 18,1\%-a él falvakban, jelentősen elmaradva a 29,5\%-os népességaránytól. Mindebből következően a naponta ingázók közel 60\%-a falusi lakos, és a hetente vagy ritkábban hazautazók több mint fele (52\%) szintén közülük kerül ki. Az arányszámok értelmezésekor itt is figyelembe kell venni azt, hogy az elmaradottabb térségek falvainak döntő többségében a közfoglalkoztatás jelenti az egyetlen reális munkavégzési lehetőséget, ez pedig erőteljesen korlátozza a mobilitást.

\section{Összegzés}

A Magyarországon a 20. század legelején megjelenő, a gazdaság és a társadalom szerkezeti átalakulásait követve mindig más feltételrendszerben működő ingázásban résztvevők fő motivációja a múltban és a jelenben is közös volt: a megfelelőnek ítélt munkahely elérése. Korántsem mindegy azonban, hogy ezért a munkahelyért milyen távolságot kell leküzdeni, mennyi és milyen plusz ráfordítás (idő, költségek stb.) árán tehető ez meg - és főként nem mellékes, hogy az ingázó életforma vállalása önkéntes, vagy a kényszer szülte a döntést.

Az már a statisztikai adatok alapszintű elemzéséből is tisztán látszik, hogy a lakóhelyük és munkahelyük közötti távolságot nem napi rendszerességgel megtevő huzamos vagy távolsági ingázók, köznapi elnevezéssel „hetelők” semelyik szempontból sincsenek kedvező helyzetben. A Központi Statisztikai Hivatal sokatmondó megfogalmazásában ők az ingázók „egy kisebb, de jóval hátrányosabb helyzetű csoportja” (KSH 2015: 8). A legfrissebb felmérések alapján közel negyedmillió ember a munkaerőmozgás és a tényleges lakóhelyváltás határmezsgyéjén mozog, döntő többségük esetében az anyagi korlátok azok, amelyek miatt kénytelenek vállalni a napokig, hetekig vagy akár hónapokig tartó távollétet otthonuktól és családjuktól.

Ez már önmagában utal egyfajta kiszolgáltatottságra, ami számos egyéb formában mutatkozik még meg (részmunkaidő, határozatlan idejű szerződések, nem térített utazási költségek magasabb aránya stb.). A statisztikai adatok alapján kirajzolódó „átlagos hetelő” középfokú végzettséggel rendelkezve fizikai munkakörben, a tercier szektorban dolgozó, Északkelet-Magyarországról vagy a fővárost körbevevő megyékből származó falusi lakos, aki vagy a 40-es éveiben járó férj, vagy a családjától még nem elszakadó, családalapítás és gyermekvállalás előtt álló huszonéves fiatal. Bármelyik is legyen, az ezzel az életformával járó fizikai és lelki megterhelést hosszabb távon aligha viseli el komolyabb károsodás nélkül a szervezete és az emberi-családi kapcsolatai - így mindenképpen érdemes közelről, az érintettek szemszögéből is megvizsgálni, milyen hatásai és következményei lehetnek a nagy távolságú, huzamos időtartamú ingázásnak. 


\section{TEMATIKUS TANULMÁNYOK - „Hetelők” Kelet-Magyarországon}

\section{Irodalom}

Beluszky P. (2004): Magyarország településföldrajza. Általános rész. Nordex Kft. Dialóg Campus Kiadó, Budapest - Pécs

Dövényi Z. (2009): A belső vándormozgalom Magyarországon: folyamatok és struktúrák. Statisztikai Szemle, 87. évf. 7-8. sz.

Forray R. K. (szerk.) (2008): A foglalkoztatottság és a munkanélküliség szerkezetét befolyásoló társadalmi-területi tényezők. Oktatáskutató és Fejlesztő Intézet, Budapest

Hardi T. (2015): A munkaügyi ingázás területi mintái Észak-Dunántúlon. Területi Statisztika, 55. évf. 2. sz., 122-141.

Kovács Z. - Egedy T. - Szabó B. (2015): Az ingázás területi jellemzőinek változása Magyarországon a rendszerváltozás után. Területi Statisztika, 55. évf. 3. sz., 233253.

KSH (2009): A foglalkoztatottak munkába járási, ingázási sajátosságai. Statisztikai Tükör, III. évf. 2. sz.

KSH (2015): 2011. évi népszámlálás 18. kötet. A foglalkoztatottak napi ingázása és közlekedése. Központi Statisztikai Hivatal, Budapest

KSH: Módszertani dokumentáció/fogalmak. (Utolsó letöltés: 2020. 04. 25.)

http://www.ksh.hu/apps/meta.objektum?p_lang=HU\&p_menu_id=210\&p_ot_ id=200\&p_obj_id=4083

Pénzes J. (2013): A foglalkoztatottság, az ingázás és a jövedelmi szint összefüggései Északkelet- és Északnyugat-Magyarországon. Területi Statisztika, 53. évf. 3. sz. 202-224.

Rácz K. (2009): Útban a szociális gazdaság felé? Kapocs, VIII. évf. 3. sz., 18-29. 